\title{
Dietary map of Nile tilapia using stable isotopes in three tropical lakes, Ethiopia
}

\author{
Tadesse Fetahi $^{1,2}$ (1) | Karl-Otto Rothhaupt ${ }^{2}$ | Frank Peeters ${ }^{2}$
}

\author{
${ }^{1}$ Department of Zoological Sciences, Addis \\ Ababa University, Addis Ababa, Ethiopia \\ ${ }^{2}$ Limnological Institute, University of \\ Constance, Konstanz, Germany

\section{Correspondence} \\ Tadesse Fetahi, Department of Zoological \\ Sciences, Addis Ababa University, Addis \\ Ababa, Ethiopia. \\ Emails: tadesse.fetahi@uni-konstanz.de or \\ tfetahi@gmail.com
}

\section{Funding information}

Alexander von Humboldt-Stiftung; Thematic Research Water Working Group of Addis Ababa University, Ethiopia

\begin{abstract}
Comprehensive analysis of food webs requires identifying dietary sources that support the production of all major organisms within the food web/food chain. Here, we use stable isotope ratios $\left(\delta^{13} \mathrm{C}, \delta^{34} \mathrm{~S}\right.$ and $\left.\delta^{15} \mathrm{~N}\right)$ to assess the relative contribution of different basal carbon sources to the diet of Nile tilapia (Oreochromis niloticus L.) in three tropical lakes Hawassa (also Awasa in literature), Ziway and Koka (Ethiopia). Computations were carried out with Stable Isotope Analysis in R (SIAR) model to quantify the dietary proportion of each prey for the tilapia fish. Basal food sources were distinguishable based on their $\delta^{13} \mathrm{C}, \delta^{34} \mathrm{~S}$ and $\delta^{15} \mathrm{~N}$ values. In Lake Ziway, macrophytes (64\%) were the dominant assimilated diet of tilapia while particulate organic matter (POM) and zooplankton contributed only $20 \%$ and $16 \%$, respectively. In parallel, Nile tilapia in Lake Hawassa assimilated macrophytes (35\%), POM (33\%) and zooplankton (32\%) at comparatively equal proportion. The dietary sources of the fish in Lake Koka were POM (49\%) and zooplankton (51\%). In contrast with earlier studies based on gut content analysis, the present results reveal that macrophytes contributed more and phytoplankton less than previously reported especially in macrophytedominated lakes Ziway and Hawassa. The ecological condition of the lakes might have been predominantly accountable for the diet change of the tilapia. As dietary data are prerequisite for food web/food chain analysis and aquaculture industry, re-evaluating the diet of aquatic organisms appear relevant.

KEYWORDS

food web, mixing models, stable isotopes, tilapia diet, tropical lakes
\end{abstract}

\section{1 | INTRODUCTION}

An understanding of food web dynamics is of growing importance for ecosystem management and sustainable utilization of resources. Food webs are good holistic ecological macrodescriptors, provide insight in biogeochemical cycles, quantify energy and describe trophic interactions within an ecosystem (Moore \& De Ruiter, 2012; Polis \& Winemiller, 1996).

Although it is vital for a holistic ecosystem understanding and management, a comprehensive and quantitative analysis of a food web requires information on availability of primary sources of organic matter and their use by primary consumers (Hershey, Fortino,
Peterson, \& Ulseth, 2009). Diet sources are essential; nevertheless, they are the most uncertain inputs in food web models, and identifying food sources that support the production of organisms within the food web is one of the most important challenges in ecological studies (Dalsgaard, St. John, Kattner, Muller-Navarra, \& Hagen, 2003; Iverson, 2009). Food web analysis begins with identification of sources of food, trophic positions and linkages (Layman et al., 2011), which traditionally has been analysed from stomach, gut or faecal content composition. Traditional (gut content analysis) methods are well-established methods and produce useful info even though it has well-recognized limitations predominantly due to variation in digestion rates of food categories (Michener \& Kaufman, 2007; Post, 2002; Rybczynski, 
Walters, Fritz, \& Johnson, 2008). Moreover, it provides information about what is ingested, but not necessarily what is assimilated (Michener \& Kaufman, 2007).

In recent years, stable isotope analysis of consumer tissues and dietary sources as well as the use of Bayesian Stable Isotope Mixing Models emerged as an alternative but complementary technique to conventional gut/stomach content analysis. Indeed, stable isotopes have increasingly demonstrated their utility in numerous recent food web studies (Fry, 2006; Gu, Schelske, \& Waters, 2011; Layman et al., 2011; Mao, Gu, Zeng, Zhou, \& Sun, 2012; Mao et al., 2014; Rao, Ning, Zhong, Jeppesen, \& Liu, 2015). Stable isotopes are especially useful because they provide time-integrated and spatial differences into trophic relationships among organisms, and thus can be used to develop models of trophic structure (Layman et al., 2011). The foods that animals eat exhibit characteristic isotopic signatures (Gannes, Del Rio, $\&$ Koch, 1998), and the stable nitrogen isotope value $\left(\delta^{15} \mathrm{~N}\right)$ indicates trophic position while the stable carbon isotope signature $\left(\delta^{13} \mathrm{C}\right)$ reveals its original sources of dietary carbon. Sulphur has been useful to complement stable $\mathrm{C}$ isotope analysis to distinguish sources of organic matter, habitat and ecosystem of organisms (Croisetie're, Hare, Tessier, \& Cabana, 2009; Godbout et al., 2010; Layman et al., 2011). Once the dietary sources have been identified, stable isotope mixing models offer an excellent way to quantify the diet of the consumer (Phillips et al., 2014). The mixing models are increasingly used to quantify consumer diets, and the dietary contribution of each prey for a consumer can be estimated with Bayesian Stable Isotope Mixing Model such as Stable Isotope Analysis in R (SIAR) (Parnell, Inger, Bearhop, \& Jackson, 2010; Parnell et al., 2012).

Food web studies employing either ecological models or stable isotopes are relatively insufficient in tropical African aquatic ecosystems (Jepsen \& Winemiller, 2002; Kupfer, Langel, Scheu, Himstedt, \& Maraun, 2006; Mao et al., 2012; Mavuti, Moreau, Munyadrorero, \& Plisnier, 1996). In Ethiopia, food web studies are an emerging field of research interest and stimulating results were obtained for some lakes (Fetahi \& Mengistou, 2007; Fetahi, Schagerl, Mengistou, \& Libralato, 2011). The food and feeding ecology of commercially important fish species were studied based on stomach/gut content analysis (Admassu \& Dadebo, 1997; Dadebo, Mohammed, \& Sorsa, 2013; Dadebo, Tesfahun, \& Teklegiorgis, 2013; Deribe et al., 2011; Desta, Borgstrøm, Rosseland, \& Dadebo, 2007; Getachew \& Fernando, 1989). According to these studies, Nile tilapia was predominantly considered a herbivore, consuming mainly pelagic phytoplankton. This was questioned by other investigators suggesting that detritus could be an equally important food source as phytoplankton (Fetahi \& Mengistou, 2007). In Ethiopia, Nile tilapia is widely distributed in almost all inland water bodies and constitutes the most commercially important species that contributes around $60 \%$ of the total landings and $97.6 \%$ of the Lake Hawassa fishery (Admassu, 1996; Bjørkli, 2004; LFDP, 1997). In most of the tropics, especially in Asia, Nile tilapia is the most used fish species in aquaculture. More insights in its feeding habits are therefore ecologically and economically important.

In this study, we use stable isotopic ratios $\left(\delta^{13} \mathrm{C}, \delta^{34} \mathrm{~S}\right.$ and $\left.\delta^{15} \mathrm{~N}\right)$ to assess the relative contribution of different basal carbon sources to the diet of Nile tilapia in three tropical lakes, Ethiopia, that have different morphological and limnological characteristics including depth and water transparency. The diet of the consumer is analysed from the assimilated food, either muscle or whole organism, and also provides time-integrated dietary insight of the fish. Computations were carried out with SIAR model to quantify the dietary proportion of each prey for the tilapia fish. Food sources included are macrophytes, phytoplankton, zooplankton and detritus (Deribe et al., 2011, 2014; Getachew \& Fernando, 1989). We hypothesized that phytoplankton and detritus are the major food sources for the energetic demands of Nile tilapia in the three lakes.

\section{2 | MATERIAL AND METHODS}

\section{1 | Study}

Lakes Hawassa, Ziway and Koka are situated in the Ethiopian rift valley (Figure 1) and are nearby to each other with similar landscape setting, land use and altitude (Willén et al., 2011). Lake Hawassa is relatively small and deep, lakes Ziway and Koka are large and shallow (Figure 1). Lake Hawassa has no surface outflow, and River TikurWuha is the only inflowing river. Lake Ziway has two inflowing rivers, Meki and Ketar Rivers, and the lake overflows towards Lake Abijata, another nearby Rift Valley Lake. Lake Koka is a reservoir formed by damming Awash River for the purpose of hydroelectricity in the late 1960s and fed by Awash and Mojo rivers. These lakes are used for domestic water use, fisheries, tourism and small-scale irrigation. Lakes Hawassa and Ziway have an extended littoral zone and are covered with emergent and submerged macrophytes, which provide feeding, breeding and nursery habitats for fish (Admassu \& Ahlgren, 2000; Bjørkli, 2004; Kibret \& Harrison, 1989). The commercially important fish species in the three lakes include Nile tilapia (Oreochromis niloticus (L.), African sharptooth catfish (Clarias gariepinus (L.) and Labeobarbus intermedius (Rüppell, 1836) (Lakes Fisheries Development Program (LFDP), 1997; Dadebo, 2000; Golubtsov, Dgebuadze, \& Mina, 2002). The climate of the region is characterized by subhumid to semi-arid with evaporation exceeding rainfall. The region experiences a dry season from November to February and a wet season from March to October (Gamachu, 1977).

\section{2 | Stable isotope sampling}

All samplings for the studied lakes were carried out monthly between October 2013 and April 2014 for seven consecutive months. We collected seven to 10 adult Nile tilapia measuring $14.5-32 \mathrm{~cm}$ total length from fishermen at each sampling date. White dorsal muscle was removed from a total of 60 tilapia at L. Hawassa, 64 at L. Ziway and 62 at L. Koka and were washed with de-ionized water, dried at $60^{\circ} \mathrm{C}$ and ground. Lake water samples were filtered onto precombusted (at $450^{\circ} \mathrm{C}$ ) Whatman GF/F glass filters for particulate organic matter (POM) analysis. All glass filters were dried at $60^{\circ} \mathrm{C}$ and packed into aluminium foil envelopes for stable isotope analysis. Before analysis, the inorganic carbon in the samples was removed with the acid 




FIGURE 1 Map of Ethiopia (inset) and the rift valley lakes with their drainage basin pattern. The broken arrows indicate the studied lakes Hawassa, Ziway and Koka (From Mengistou, 1989). Lakes Hawassa, Ziway and Koka have surface area $\left(\mathrm{km}^{2}\right)$ of $88,434,200$, and mean depth (m) of 11 , 2.5 and 5 , respectively fumigation technique (Lorrain, Savoye, Chauvaud, Paulet, \& Naulet, 2003). Macrophytes (Typha, Cyperus, Arundo and Potamogeton) were collected, and samples were placed in polyethylene bags, stored in an ice box. Epiphytic and other materials were removed from the leaf samples with gentle wiping and washing with tap water and rinsed with deionized water, and then, leaves were dried at $60^{\circ} \mathrm{C}$ and finally ground. Zooplankton was collected from the pelagic station with a vertical haul using a $64-\mu \mathrm{m}$ mesh zooplankton net. The net was towed from 3 to $4 \mathrm{~m}$ to the lake surface, and zooplankton was kept alive for $4 \mathrm{hr}$ in filtered lake water to allow gut clearance. Zooplankton was separated into two categories, Copepoda and Cladocera, and individuals were hand-picked (between 250 and 300 individuals per each sample), dried at $60^{\circ} \mathrm{C}$ and stored in a desiccator.

Lipid extraction or correction was made for apposite samples as lipids are depleted in ${ }^{13} \mathrm{C}$ compared with muscle tissues or whole organisms, and the lipid content of animal tissue is variable (Peterson \& Fry, 1987; Ryan et al., 2012; Yurkowski, Hussey, Semeniuk, Ferguson, $\&$ Fisk, 2015). For Nile tilapia, lipids were extracted three times using 3-4 $\mathrm{ml}$ of 2:1 chloroform:methanol solvent and rinsed three times with deionized water (McMeans, Olin, \& Benz, 2009). However, the mass balance lipid correction model of Smyntek et al. was used for zooplankton to correct stable isotope values for lipid content (Smyntek, Teece, Schulz, \& Thackeray, 2007).

\section{3 | Stable isotope measurement}

All samples were dried, ground and weighed (0.7-1.5 mg) using a Mettler Toledo microbalance. Samples were combusted in an elemental analyser, and stable isotopes of carbon, nitrogen and sulphur were analysed using Isoprime Isotope Ratio Mass Spectrometer (IRMS) at the Limnological Institute of Constance University, Germany. The ratios of heavy to light stable isotopes $\left({ }^{13} \mathrm{C} /{ }^{12} \mathrm{C}\right.$ or $\left.{ }^{15} \mathrm{~N} /{ }^{14} \mathrm{Nor}{ }^{34} \mathrm{~S} /{ }^{32} \mathrm{~S}\right)$ were reported in the conventional delta $(\delta)$ notation as parts per thousand (permil, \%o) relative to the international standards.

\section{4 | Bayesian mixing model}

The combined mean values of $\delta^{13} \mathrm{C}, \delta^{34} \mathrm{~S}$ and $\delta^{15} \mathrm{~N}$, and SIAR model were used to examine how the basal carbon sources in the three lake ecosystems were successively transferred to higher trophic levels. The relative proportion of each of the potential food sources to the diet of Nile tilapia was calculated using the mixed model SIAR package (Stable Isotope Analysis in R, Parnell et al., 2010), which follows a Bayesian approach to estimate the probability distribution of prey contribution to a consumer diet. The SIAR model includes various sources of uncertainty in input parameters such as Trophic Discrimination Factors (TDF), as well as calculates the proportional dietary source estimates 
even when $>n+1$ sources ( $n=$ number of isotope systems) (Hopkins \& Ferguson, 2012; Phillips et al., 2014). Correspondingly, the package enables user to depict more accurately the most likely proportional contribution of sources to consumers (Layman et al., 2011). The required inputs for SIAR include isotopic signature of potential preys (food sources), isotopic signature of consumers and values for TDF. Lakes Hawassa, Ziway and Koka are eutrophic and macrophytes form fringe to lakes, and we assumed that phytoplankton is the dominate contributor of POM followed by macrophytes with no major influence from terrestrial organic matter. TDF $(\Delta$, mean $\pm S D)$ for carbon, sulphur and nitrogen was calculated using the difference in delta ( $\delta$ ) values between a food resource $(F)$ and a consumer $(K)$, where $\Delta=\delta \mathrm{K}-\delta \mathrm{F}$.

\section{5 | Statistical analyses}

Zooplankton in our study was categorized into Copepoda and Cladocera, and their $\delta^{13} \mathrm{C}$ values were compared using MannWhitney to consider them independently in the SIAR model. The effect of acidification on $\delta^{13} \mathrm{C}$ of POM was evaluated by examining differences between bulk (before acidification) and acidified (after removal of inorganic carbon) values using Wilcoxon test. All statistical tests were performed using SPSS ver. 20. SigmaPlot version 11 was used for producing some graphs.

\section{3 | RESULTS}

\section{1 | Source contribution of tilapia diet}

The mean isotope values of $\delta^{13} \mathrm{C}, \delta^{34} \mathrm{~S}$ and $\delta^{15} \mathrm{~N}$ for POM, macrophytes, zooplankton and Nile tilapia fish for three rift valley lakes are shown in Table 1. POM and macrophytes were considered as basal food sources and were discriminated in their $\delta^{13} \mathrm{C}, \delta^{15} \mathrm{~N}$ and $\delta^{34} \mathrm{~S}$ isotopic values. The ratio for acidified and nonacidified POM was congruent for Lake Ziway (Wilcoxon test, $p>$.05) and significantly different for Hawassa and Koka $(p<.05)$. Thus, the former values were used in the present analysis. Carbon stable isotopes of macrophytes were distributed over a larger range from -6.8 to -28.03 . Cyperus and Arundo \& Typha were the most ${ }^{13} \mathrm{C}$-depleted taxa in Lakes Hawassa and Ziway, respectively. Potamogeton was the most ${ }^{13} \mathrm{C}$-enriched macrophytes.

In L. Ziway, the mean $\delta^{13} \mathrm{C}$ signature of Nile tilapia (-22.57\%o) was higher than that of POM $(-23.28 \%)$, lower than some macrophytes in particular to Potamogeton (-9.08\%o) and of the zooplankton
TABLE 1 Stable isotope signatures $\left(\delta^{13} \mathrm{C}, \delta^{34} \mathrm{~S}\right.$ and $\left.\delta^{15} \mathrm{~N}\right)$ of Nile tilapia and potential dietary sources in three study lakes sampled between October 2013 and April 2014

\begin{tabular}{|c|c|c|c|c|c|c|c|}
\hline \multirow[b]{2}{*}{ Lake } & \multirow[b]{2}{*}{ Species } & \multicolumn{2}{|c|}{$\delta^{13} \mathrm{C}(\%)$} & \multicolumn{2}{|c|}{$\delta^{34} S(\% \circ)$} & \multicolumn{2}{|c|}{$\delta^{15} \mathrm{~N}(\%)$} \\
\hline & & Mean & $S D$ & Mean & $S D$ & Mean & $S D$ \\
\hline \multirow[t]{9}{*}{ Hawassa } & $\begin{array}{l}\text { Nonacidified particulate } \\
\text { organic matter (POM) }\end{array}$ & -23.71 & 0.27 & 8.27 & 1.14 & 8.85 & 3.78 \\
\hline & Acidified POM & -23.12 & 0.43 & 6.06 & 1.31 & 12.72 & 3.55 \\
\hline & Arundo & -13.18 & 0.28 & 9.07 & 0.84 & 2.13 & 1.8 \\
\hline & Potamogeton & -7.8 & 0.66 & 8.68 & 1.15 & 6.56 & 1.36 \\
\hline & Macrophyte 1 & -6.4 & 1.08 & 10.39 & 0.59 & 4.85 & 1.78 \\
\hline & Cyperus & -26.3 & 2.27 & 5.76 & 2.6 & 4.56 & 2.1 \\
\hline & Cladocera & -21.4 & 0.3 & 10.69 & 0.1 & 7.14 & 0.08 \\
\hline & Copepoda & -20.13 & 1.1 & 3.98 & 0.92 & 9.05 & 1.05 \\
\hline & Nile tilapia & -21.56 & 0.24 & 11.37 & 3.2 & 8.21 & 1.16 \\
\hline \multirow[t]{9}{*}{ Ziway } & Nonacidified POM & -23.28 & 1.04 & 6.03 & 1.00 & 13.8 & 2.59 \\
\hline & Acidified POM & -23.27 & 0.66 & 4.47 & 0.91 & 12.43 & 3.54 \\
\hline & Arundo & -27.03 & 0.47 & 11.04 & 1.47 & 2.65 & 2.25 \\
\hline & Potamogeton & -9.08 & 3.56 & 9.41 & 0.64 & 11.51 & 1.61 \\
\hline & Cyperus & -19.11 & 9.38 & 7.07 & 1.45 & 2.03 & 0.5 \\
\hline & Typha & -26.61 & 0.4 & 8.43 & 1.65 & 1.67 & 1.82 \\
\hline & Cladocera & -18.77 & 2.1 & 3.32 & 4.1 & 10.78 & 3.19 \\
\hline & Copepoda & -19.14 & 0.98 & 4.73 & 0.85 & 13.01 & 4.44 \\
\hline & Nile tilapia & -22.57 & 1.82 & 5.98 & 1.34 & 6.72 & 1.62 \\
\hline \multirow[t]{6}{*}{ Koka } & Nonacidified POM & -22.96 & 0.36 & 4.98 & 0.67 & 19.85 & 2.82 \\
\hline & Acidified POM & -21.89 & 0.28 & 4.27 & 1.16 & 19.96 & 3.58 \\
\hline & Nymphaea (Water Lily) & -28.03 & 0.52 & 5.68 & 0.8 & 14.01 & 0.74 \\
\hline & Cladocera & -20.91 & 0.65 & 4.69 & 0.91 & 17.19 & 0.66 \\
\hline & Copepoda & -20.77 & 0.36 & 5.99 & 1.27 & 16.41 & 0.80 \\
\hline & Nile tilapia & -23.5 & 0.77 & 7.49 & 0.44 & 15.07 & 1.12 \\
\hline
\end{tabular}


groups Cladocera $(-18.77 \%$ o) and Copepoda $(-19.14 \%$ ). There is no significant difference (Mann-Whitney, $p>.05$ ) in $\delta^{13} \mathrm{C}$ signatures of Cladocera and Copepoda, and they were treated as a single zooplankton group for SIAR model. The box plot in Figure 2 demonstrates the distribution of $\delta^{34} \mathrm{~S}$ values across all studied ecosystems (Figure 2a) while Figure $2 \mathrm{~b}$ shows bidirectional scatter plot $\delta^{34} \mathrm{~S}$ vs. $\delta^{15} \mathrm{~N}$. Lake Hawassa is more enriched compared to lakes Ziway and Koka revealing the potential use of sulphur isotope in discriminating habitats and ecosystems. The distributions of $\delta^{15} \mathrm{~N}$ values among the lakes (Figure 2c) were also significantly different (Mann-Whitney, $p>$.05) discriminating Lake Koka from the other two.

The bidirectional scatter plot of $\delta^{13} \mathrm{C}$ vs. $\delta^{15} \mathrm{~N}$ (Figure 3) depicts the distribution of stable carbon ratios of food sources and a model consumer Nile tilapia. It shows that the contribution of macrophytes to the assimilated diet of tilapia is high in Lake Ziway compared to lakes Hawassa and Koka.

The relative quantitative proportion of each of the potential food sources to the diet of tilapia fish for the three lakes is shown in Figure 4. The mixing model indicated that POM contributed $20 \%$ on average to Lake Ziway tilapia-assimilated diet. Of this, the relative contribution of phytoplankton was $15 \%$. The contribution of macrophytes to the diet of Nile tilapia in Lakes Ziway and Hawassa was high, making it the dominant food source in L. Ziway (64\%) and also in Lake Hawassa (35\%). In Lake Koka, however, POM (49\%) and zooplankton (51\%) were the main dietary sources of Nile tilapia.

\section{4 | DISCUSSION}

\section{1 | Stable isotope composition}

The isotopic signatures of the basal food sources in tropical lakes Hawassa, Ziway and Koka showed a wide variation in $\delta^{13} \mathrm{C}, \delta^{34} \mathrm{~S}$ and $\delta^{15} \mathrm{~N}$ values. The $\delta^{15} \mathrm{~N}$ values of macrophyte taxa were variable with a range of about $12 \%$, which, however, is in accordance with several studies (King et al., 2009; and cited therein). Similarly, the $\delta^{13} \mathrm{C}$ of macrophytes were much more variable reaching differences up to $20 \%$ (Table 1), which appears large as freshwater macrophytes belong to the C3 group of plants (Beer \& Wetzel, 1982). The large (a)


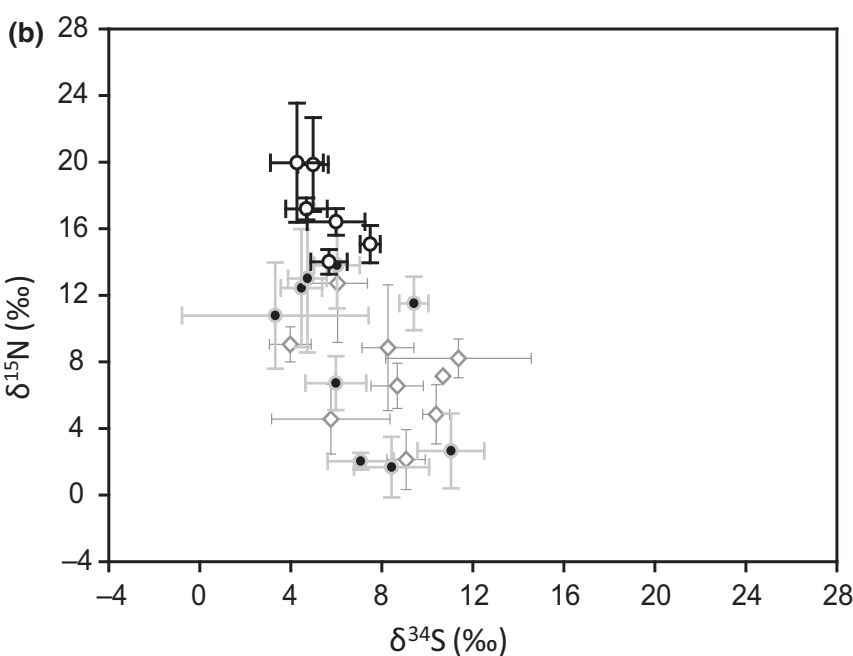

FIGURE 2 Box plots of stable isotopes sulphur (a) and nitrogen (c), and a biplot of $\delta^{34} \mathrm{~S} v$ s. $\delta^{15} \mathrm{~N}$ for potential preys and consumer tilapia are shown across the three study lake ecosystems Hawassa, Ziway and Koka, Ethiopia. Sulphur distinguished Lake Hawassa from the other two shallow lakes while stable nitrogen discriminated Lake Koka from the other two. Symbols in (b) open diamond-Hawassa; dark circle-Ziway; open circle-Koka 



FIGURE 3 Isoscape biplot of $\delta^{13} \mathrm{C}(\%)$ versus $\delta^{15} \mathrm{~N}(\%)$ for lakes Hawassa, Ziway and Koka, Ethiopia. The grey arrows at Lake Hawassa biplot are to indicate which value belongs to which organism. However, we have removed arrows in subsequent biplots to make the graph clear and attractive but organisms stand near their values

FIGURE 4 Bar graph showing dietary contribution of various primary carbon sources to the diet of Nile tilapia computed by Stable Isotope Analysis in R (SIAR) mixing model in the tropical rift valley lakes Hawassa, Ziway and Koka. Note: other macrophytes are pool of Arundo, Cyperus and macrophyte 1 (local name Shark) in L. Hawassa and Arundo, Cyperus and Typha in L. Ziway. Greyscale (from light to dark) indicates 95,75 and $25 \%$ confidence intervals, respectively
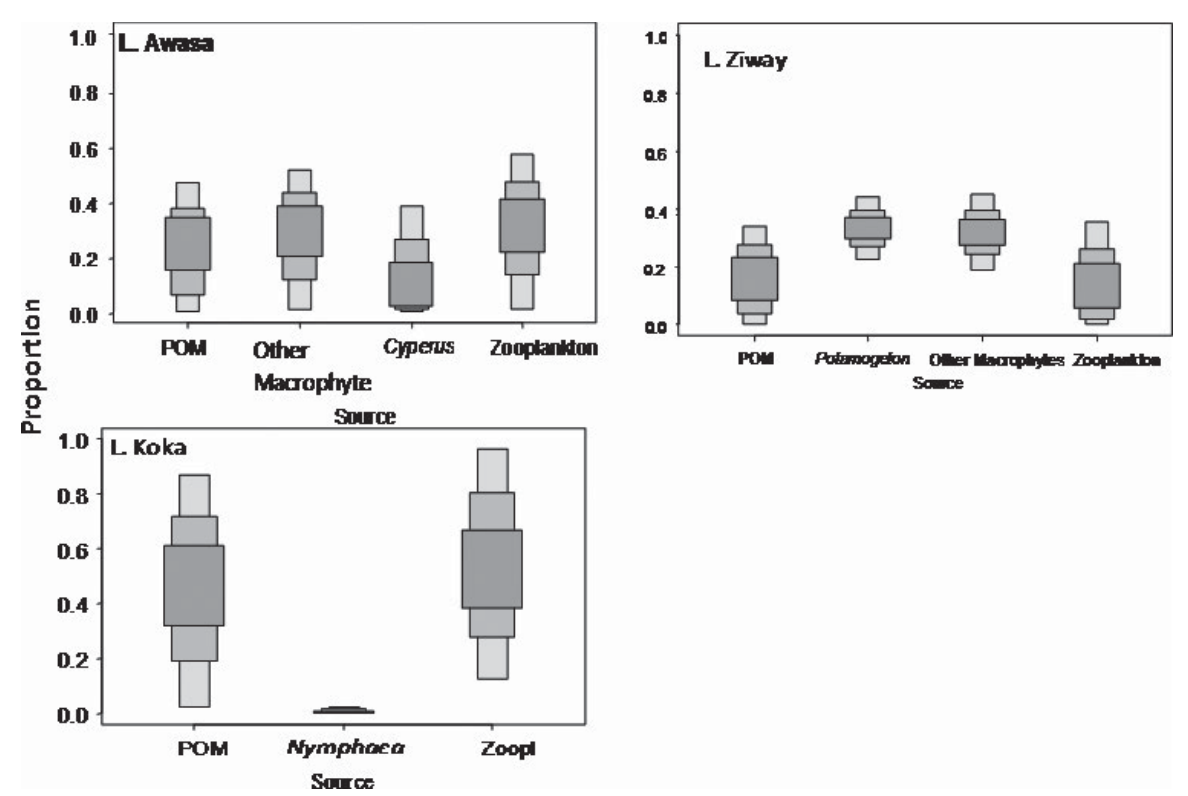

difference observed could be due to enzymatic discrimination during photosynthesis and the fixation of $\mathrm{HCO}_{3}^{-}$rather than dissolved $\mathrm{CO}_{2}$ (Fry, 1991; Raven et al., 2002). In an experimental study, the use of
$\mathrm{HCO}_{3}^{-}$for photosynthesis has been shown for all Potamogeton species that has entirely submersed foliage (homophyllous species) (Bodner, 1994). Potamogeton in Lakes Hawassa and Ziway are homophyllous 
species as well as the macrophyte species most enriched in ${ }^{13} \mathrm{C}$. Since $\delta^{13} \mathrm{C}_{\text {of }} \mathrm{HCO}_{3}^{-}$is on average $8 \%$ higher than that of dissolved free $\mathrm{CO}_{2}$ (Mook, Bommerson, \& Stavermen, 1974), the ${ }^{13} \mathrm{C}$ enrichment of Potamogeton in this study lakes substantiate their use of $\mathrm{HCO}_{3}^{-}$as $\mathrm{C}$ source.

Interestingly, stable isotope ratios of nitrogen $\left(\delta^{15} \mathrm{~N}\right)$ were notably high for organisms inhabited in Lake Koka compared to lakes Hawassa and Ziway. Land-use practices and anthropogenic factors can influence $\delta^{15} \mathrm{~N}$ (Borderelle, Gerdeaux, Giraudoux, \& Verneaux, 2009; Davias, Kornis, \& Breitburg, 2014). However, all lakes are located in the same geographical location with similar land use. Hence, the difference could be related to deferential use of ammonium nitrogen instead of nitrate by primary producers. If available, ammonium is assimilated more rapidly compared to nitrate (Wang et al., 2014) with ammonium enriched in ${ }^{15} \mathrm{~N}$ relative to nitrate (Granger et al., 2011). The nitrogen nutrition of the primary producers in Lake Koka could be $\mathrm{NH}_{4}^{+}(162.4 \pm 49.4 \mu \mathrm{g} / \mathrm{L}, \pm S D)$, the primary form of nitrogen in the lake, leading to high $\delta^{15} \mathrm{~N}$ values in successive trophic levels. In contrary, in phosphorus-limited system, where $N$ is in excess of demand, plant uptake of $N$ exhibits fractionation against the heavier ${ }^{15} \mathrm{~N}$ isotope leading to lower plant $\delta^{15} \mathrm{~N}$ values (King et al., 2009; Montoya, 2007), a possible cause for Lake Hawassa lower delta values (Table 1; Lake Hawassa soluble reactive phosphorus, $6.00 \pm 1.23 \mu \mathrm{g} / \mathrm{L}$, was low compared to Lake Koka $34.36 \pm 5.53 \mu \mathrm{g} / \mathrm{L}, \pm S D$ ). Nevertheless, the studied rift valley lakes have high $\delta^{15} \mathrm{~N}$ values compared to other lakes (Rao et al., 2015).

The box plot and biplot of $\delta^{34} \mathrm{~S}$ across the habitats (Figure 2a,b) were able to distinguish Lake Hawassa from the other two shallow lakes demonstrating the potential use of sulphur isotope in discriminating habitats and ecosystems. It specifically discriminate organisms that depend on either water column- or sediment-based nutrition (Croisetie 're et al., 2009). Lake Hawassa is relatively deep lake (max. depth $22 \mathrm{~m}$ ), where the sediment and water column are separated except during mixing periods in June and July following stratification (Taylor \& Gebre-Mariam, 1989). Organisms in Lake Hawassa are relatively ${ }^{34} \mathrm{~S}$ enriched compared to Lakes' Ziway and Koka (Figure 2; Table 1). These latter lakes are shallow lakes ( $<7 \mathrm{~m}$ max. depth) and has little disparity between sediment and water column owing to frequent re-suspension. The major cause for the differences in water column and sedimentary $\delta^{34} S$ values is mainly from the fractionation of $S$ isotopes during sulphate reduction by bacteria (Canfield, 2001). These sulphate-reducing bacteria, normally inhabiting in anoxic sediment, produce sulphide-depleted ${ }^{34} \mathrm{~S}$ during their metabolism (Jones \& Starkeyr, 1957; Harrison \& Thode, 1958; Kaplan \& Rittenberg 1964). In natural marine environments, for example, sulphides are commonly depleted in ${ }^{34} \mathrm{~S}$ by-45\% to $-70 \%$ o relative to seawater sulphate (Brunner \& Bernasconi, 2005). Our findings support other studies. Stable sulphur isotopes were used to discriminate food chains that are based in the water column from those based on sedimentary detritus; animals feeding in the water column were enriched in ${ }^{34} \mathrm{~S}$ compared to those feeding on sediment (Croisetie're et al., 2009; Peterson \& Fry, 1987; McCutchan et al. 2003). On the other hand, the concentration of 34-sulphur in terminal Lake Hawassa could upsurge through time.

\subsection{Dietary sources to Nile tilapia}

Nile tilapia is mainly herbivore, feeding mostly on algae and plant material but it also consumes animal food sources primarily zooplankton (Getabu, 1994; Getachew \& Fernando, 1989; Moriarty \& Moriarty, 1973). Zooplankton, in turn, consumes a wide variety of POM, which constitutes phytoplankton, bacteria, protozoa and detrital particles. The comparable $\delta^{13} \mathrm{C}$ values of zooplankton and POM (Figures 3 and 4) suggested that POM made up a substantial food source for the zooplankton. Consequently, we calculated $56 \%$ algal content to the assimilated diet of zooplankton with the assumption of congruent assimilative efficiency of phytoplankton and detritus. We rejected our hypothesis that phytoplankton and detritus were the primary diet of Nile tilapia across the studied lakes. In contrast to the previous dietary assessments based on gut content analysis (Deribe et al., 2014; Getachew \& Fernando, 1989), the present result revealed that the contribution of macrophytes to the assimilated diet of tilapia has relatively increased while phytoplankton biomass constituted less than expected especially in macrophyte-dominated lakes Ziway and Hawassa (Figures 4 and 5). In Lake Ziway, macrophytes (64\%) were the dominant diet of tilapia while POM and zooplankton contributed only $20 \%$ and $16 \%$, respectively (Figure 5). Our results support the study of Rao et al. (2015) who revealed high contribution of macrophytes (54\%) in the diet of Nile tilapia in South Lake, China. Rao et al. (2015) reported that large-bodied tilapia fish fed mainly on submerged macrophytes while small-bodied fish $(<6 \mathrm{~cm})$ consume primarily on periphyton and phytoplankton demonstrating the feeding habits of Nile tilapia were size dependent. Several other studies also showed that Nile tilapia considerably consume macrophytes (Adámek \& Mareš, 1990; Chapman \& Fernando, 1994; Khallaf \& Alne-na-ei, 1987).

Nile tilapia uses filter feeding and visual predation to catch its prey (Beveridge \& Baird, 2000). While adult, the fish stop preying visually and the mucus secreted by the gill rakers trap only small planktonic organisms (Gophen, Drenner, \& Vinyard, 1983; Lazzaro, 1987, 1991; Sanderson et al., 1996; Ibrahim et al. 2015). Hence, plankton could be the dominant diet item of tilapia in eutrophic phytoplanktondominated lakes (Getachew \& Fernando, 1989). However, the phytoplankton biomass in Lake Ziway is decreasing (Tilahun, 2007) and even some researchers indicated that the lake is heading to oligotrophication, which is associated to nonalgal turbidity of the lake (Beneberu \& Mengistou 2009). Furthermore, Nile tilapia in Lake Ziway could have difficulty of filtering plankton from turbid POM due to high load of suspended sediments (Ash mass or inorganic content was calculated $44.3 \pm 19 \mathrm{mg} / \mathrm{L}$ compared to Lake Hawassa $3.5 \pm 6.3$ ) that would be a driving force to switch its diet to the available macrophytes, which grows all year around as a preferred source of food and quick to satiate compared to POM. Besides, macrophytes in Lake Ziway contribute more carbon to the system than phytoplankton (Tamire \& Mengistou, 2014). Additionally, zooplankton, in particular cladocera, is very low in abundance and biomass to be a vital source of energy to Nile tilapia in the lake (Dagne, 2010).

Similarly, Nile tilapia in Lake Hawassa has assimilated macrophytes (35\%), POM (33\%) and zooplankton (32\%) at comparatively equal 
FIGURE 5 Schematic diagram showing carbon flow from primary carbon sources (phytoplankton, macrophytes, detritus and zooplankton) towards Nile tilapia in lakes Hawassa, Ziway and Koka using stable carbon isotope ratios computed with Stable Isotope Analysis in R (SIAR) model. Algal content to AFDW (ash-free dry weight) ratio of $56 \%$ was assumed (Reynolds, 1984) to apportion POM to phytoplankton and detritus

proportion. This is inconsistent with Getachew and Fernando (1989) who reported that phytoplankton was the predominant diet of the fish. The diet analysis using SIAR model showed that Nile tilapia consumed only $18.5 \%$ of phytoplankton biomass in Lake Hawassa (Figure 5) suggesting a large portion of phytoplankton primary production was not utilized by the species. Interestingly, based on long-term plankton data analysis of Lake Hawassa, the phytoplankton biomass was found to be lower than previously reported (Fetahi \& Mengistou, 2014). Compared to Lake Ziway, zooplankton in Lake Hawassa was an important trophic link between basal food sources and tilapia fish supporting the previous conclusion based on a food web study (Fetahi \& Mengistou, 2007). However, the zooplankton composition was depauperate and the abundance, in particular cladocera abundance, was insufficient to utilize the phytoplankton biomass available in the lake (Fetahi \& Mengistou, 2014). Earlier, Fetahi and Mengistou (2007) remarked that much of the phytoplankton primary production in Lake Hawassa was not effectively utilized by herbivore. Of the three studied lakes, Lake Koka is the lake in which the contribution of zooplankton to the diet of tilapia is largest reaching $51 \%$ of the assimilated energy of Nile tilapia demonstrating the critical link of zooplankton between basal carbon sources and higher trophic level. The effect of size on diet of tilapia should be the focus of future studies to complete the knowledge of Nile tilapia diet. Juvenile Nile tilapia $(<6 \mathrm{~cm})$ can consume considerable amount of phytoplankton even in macrophyte-dominated lakes (Rao et al., 2015). The feeding habit of tilapia in Lake Koka, however, did not include macrophytes as a major diet (Figure 5); it primarily consumes POM and zooplankton at equal proportion.

Stable isotope analyses coupled with SIAR model were a useful tool to define the feeding habit of Nile tilapia in the three tropical lakes. The SIAR model indicated that the assimilated diet of Nile tilapia was primarily macrophytes, and this study provides the first evidence that the contribution of macrophyte to the diet of tilapia in these lakes were significant, proportioning up to $64 \%$ for Lake Ziway. The ecological condition of the lakes might have been predominantly accountable for the present dietary map of the Nile tilapia in the lakes. In lakes Koka and Hawassa, zooplankton is a critical energy link between basal carbon sources and Nile tilapia. Detrital food chain appears more important in Lake Hawassa as previously suggested (Fetahi \& Mengistou, 2007) but also in Lake Koka. As dietary data are prerequisite for food web/food chain analysis and aquaculture industry, re-evaluating the diet of aquatic organisms appear relevant. The diet of tilapia is size dependent and future study should focus on juvenile tilapia $(<6 \mathrm{~cm})$ to complete our understanding of tilapia diet in these rift valley lakes. Moreover, macrophytes, which are subjected to human use and modification, should be given due attention for the overall production and sustainable utilization of the ecosystems.

\section{ACKNOWLEDGEMENTS}

We are grateful to Dr. Koos Vijverberg, who kindly read the draft manuscript and gave us valuable comments. Sincere thanks goes to Dr. Andrew Parnell for supporting us while developing SIAR model. We thank two anonymous reviewers and the editor for their helpful and constructive comments. Mr. Mathios Hailu and Mr. Kassahun Tessema are gratefully acknowledged for their help during field and laboratory works. We would like to thank Dr. Elisabeth Yohannes, Head of the Stable Isotope Laboratory at Limnological Institute, University of Constance, for her support. We thank Mr. Wolfgang 
Kornberger and Ms. CorinnaWaider for their support during preparation and stable isotope analysis at limnological institute. This work was financially supported by Alexander von Humboldt Foundation. The field work was supported by Thematic Research Water Working Group of Addis Ababa University, Ethiopia.

\section{REFERENCES}

Adámek, Z., \& Mareš, J. (1990). Results of pilot experiments in tilapia (Oreochromis niloticus) cage culture under pond conditions in Czechoslovakia. In R. Berka, \& V. Hilge (Eds.), Proceedings of FAO-EIFAC symposium on production enhancement in still-water pond culture (pp. 351-354). Prague, Czech Republic: VúRH Vodòany.

Admassu, D. (1996). The breeding season of tilapia, Oreochromisniloticus L. in Lake Hawassa (Ethiopian rift valley). Hydrobiologia, 337, 77-83.

Admassu, D., \& Ahlgren, I. (2000). Growth of juvenile tilapia, Oreochromis niloticus L. from Lakes Zwai, Langeno and Chamo (Ethiopian rift valley) based on otolith micro-increment analysis. Ecology of Freshwater Fish, 9, 127-137.

Admassu, D., \& Dadebo, E. (1997). Diet composition, length-weight relationship and condition factor of Barbus species Ruippell, 1836 (Pisces: Cyprinidae) in Lake Hawassa, Ethiopia. SINET: Ethiopian Journal of Science, 20, 13-30.

Beer, S., \& Wetzel, R. G. (1982). Photosynthesis is submersed macrophytes of a temperate lake. Plant Physiology, 70, 488-492.

Beneberu, G., \& Mengistou, S. (2009). Oligotrophication trend of Lake Ziway, Ethiopia. SINET: Ethiopian Journal of Science, 32, 141-148.

Beveridge, M. C. M., \& Baird, D. J. (2000). Diet, feeding and digestive physiology. In M. C. M. Beveridge, \& B. J. Mcandrew (Eds.), Tilapias: Biology and exploitation (pp. 59-87). Stirling: University of Stirling. https://doi. org/10.1007/978-94-011-4008-9 3

Bjørkli, S. G. (2004). The fisheries in Lake Hawassa, Ethiopia; estimation of annual yield. Master thesis, $\mathrm{A}^{\circ} \mathrm{s}$, Agricultural University of Norway. Retrieved from http://msc_thesis_svein_gunnar_bj_rkli_2004pdf

Bodner, M. (1994). Inorganic carbon source for photosynthesis in the aquatic macrophytes Potamogeton natans and Ranunculus fluitans. Aquatic Botany, 48, 109-120.

Borderelle, A. L., Gerdeaux, D., Giraudoux, P., \& Verneaux, V. (2009). Influence of watershed's anthropogenic activities on fish nitrogen and carbon stable isotope ratios in nine French lakes. Knowledge and Management of Aquatic Ecosystems, 392, 01-13. https://doi. org/10.1051/kmae/2009003

Brunner, B., \& Bernasconi, S. M. (2005). A revised isotope fractionation model for dissimilatory sulfate reduction in sulfate reducing bacteria. Geochimica et Cosmochimica Acta, 69, 4759-4771. https://doi. org/10.1016/j.gca.2005.04.015

Canfield, D. E. (2001). Isotope fractionation by natural populations of sulfate-reducing bacteria. Geochimica et Cosmochimica Acta, 65, 1117-1124.

Chapman, G., \& Fernando, C. H. (1994). The diets and related aspects of feeding of Nile tilapia (Oreochromis niloticus L.) and common carp (Cyprinus carpio L.) in lowland rice fields in northeast Thailand. Aquaculture, 123, 281-307.

Croisetie 're, L., Hare, L., Tessier, A., \& Cabana, G. (2009). Sulphur stable isotopes can distinguish trophic dependence on sediments and plankton in boreal lakes. Freshwater Biology, 54, 1006-1015.

Dadebo, E. (2000). Reproductive biology and feeding habits of the cat fish Clarias gariepinus Burchel in Lake Hawasssa, Ethiopia. SINET: Ethiopian Journal of Science, 17, 53-69.

Dadebo, E., Mohammed, A., \& Sorsa, S. (2013). Food and feeding habits of the straightfin Barb Barbus paludinosus (PETERS, 1852) (Pisces: Cyprinidae) in Lake Ziway, Ethiopia. Ethiopian Journal of Biological Sciences, 12, 135-150.
Dadebo, E., Tesfahun, A., \& Teklegiorgis, Y. (2013). Food and feeding habits of the African big barb Labeobarbus intermedius (Rüppell, 1836) (Pisces: Cyprinidae) in Lake Koka, Ethiopia. Journal of Agricultural Research and Development, 3, 049-058.

Dagne, A. (2010). Zooplankton community structure, population dynamics and production in relation to abiotic and biotic factors in Lake Ziway, Ethiopia. PhD Dissertation, Vienna University, Austria.

Dalsgaard, J., St. John, M., Kattner, G., Muller-Navarra, D., \& Hagen, W. (2003). Fatty acid trophic markers in the pelagic marine environment. Advances in Marine Biology, 46, 25-34.

Davias, L. A., Kornis, M. S., \& Breitburg, D. L. (2014). Environmental factors influencing $\mathrm{d} 13 \mathrm{C}$ and $\mathrm{d} 15 \mathrm{~N}$ in three Chesapeake Bay fishes. ICES Journal of Marine Science, 71, 689-702.

Deribe, E., Masresha, A. E., Gade, P. A., Berger, S., Rosseland, B. O., Borgstrøm, R., Dadebo, E., Gebremariam, Z., Eklo, O. M., Skipperud, L., \& Salbu, B. (2014). Bioaccumulation of mercury in fish species from the Ethiopian Rift Valley Lakes. International Journal of Environmental Protection, 4, 15-22. https://doi.org/10.1111/j.1095-8649.2009.02402.x

Deribe, E., Rosseland, B. O., Borgstrøm, R., Salbu, B., Gebremariam, Z., Dadebo, E., ... Eklo, O. M. (2011). Bioaccumulation of persistent organic pollutants (POPs) in fish species from Lake Koka, Ethiopia: The influence of lipid content and trophic position. Science of the Total Environment, 410-411, 136-145.

Desta, Z., Borgstrøm, R., Rosseland, B. O., \& Dadebo, E. (2007). Lower than expected mercury concentration in piscivorous African sharptooth catfish Clarias gariepinus (Burchell). Science of the Total Environment, 376, 134-142.

Fetahi, T., \& Mengistou, S. (2007). Trophic analysis of Lake Hawassa, Ethiopia, using mass-balance Ecopath model. Ecological Modelling, 201, 398-408.

Fetahi, T., \& Mengistou, S. (2014). Long-term changes in phyto- and zooplankton communities of Lake Hawassa, Ethiopia. Ethiopian Journal of Biological Sciences, 13, 69-86.

Fetahi, T., Schagerl, M., Mengistou, S., \& Libralato, S. (2011). Food web structure and trophic interactions of a tropical highland lake, Ethiopia. Ecological Modelling, 222, 804-813.

Fry, B. (1991). Stable isotope diagrams of freshwater food webs. Ecology, 72, 2293-2297.

Fry, B. (2006). Stable isotope ecology. New York: Springer-Verlag New York Inc.

Gamachu, D. (1977). Aspects of climate and water budget in Ethiopia. Master thesis, Addis Ababa University Press, Addis Ababa, Ethiopia.

Gannes, L. Z., Del Rio, C. M., \& Koch, P. (1998). Natural abundance variations in stable isotopes and their potential uses in animal physiological ecology. Comparative Biochemistry and Physiology, 119A, 725-737.

Getabu, A. (1994). A comparative study on the feeding habits of Oreochromis niloticus in Nyanza Gulf, Lake Victoria and sewage ponds. In E. Okemwa, E. Wakwabi, \& A. Getabu (Eds.), Proceedings of the second EEC regional seminar on recent trends of research on Lake Victoria Fisheries (pp. 93-103). Kisumu, Kenya: ICIPE Press.

Getachew, T., \& Fernando, C. H. (1989). The food habits of an herbivorous fish (Oreochromis niloticus L.) in Lake Hawassa, Ethiopia. Hydrobiologia, 174, 195-200

Godbout, L., Trudel, M., Irvine, J. R., Wood, C. C., Grove, M. J., Schmitt, A. K., \& McKeegan, K. D. (2010). Sulfur isotopes in otoliths allow discrimination of anadromous and non-anadromous ecotypes of sockeye salmon (Oncorhynchus nerka). Environmental Biology of Fishes, 89, 521-532.

Golubtsov, A. S., Dgebuadze, Y. Y., \& Mina, M. V. (2002). Fishes of the Ethiopian rift valley. In C. Tudorancea, \& W.D. Taylor (Eds.), Ethiopian rift valley lakes: Biology of inland water series (pp. 167-258). Leiden, The Netherlands: Backhuys Publishers.

Gophen, M., Drenner, R. W., \& Vinyard, G. G. (1983). Fish introductions into Lake Kinneret - Call for Concern. Aquaculture Research, 14, 43-45. https://doi.org/10.1111/j.1365-2109.1983.tb00053.x 
Granger, J., Prokopenko, M. G., Sigman, D. M., Mordy, C. W., Morse, Z. M., \& Morales, L. V. (2011). Couple nitrification-denitrification in sediment of the eastern Bering Sea shelf leads to $15 \mathrm{~N}$ enrichment of fixed $\mathrm{N}$ in shelf waters. Journal of Geophysical Research: Oceans, 116, C11006.

Gu, B., Schelske, C. L., \& Waters, M. N. (2011). Patterns and controls of seasonal variability of carbon stable isotopes of particulate organic matter in lakes. Oecologia, 165, 1083-1094.

Harrison, A. G., \& Thode, H. G. (1958). Mechanism of the bacterial reduction of sulphate from isotope fractionation studies. Transactions of the Faraday Society, 54, 84-92.

Hershey, A. E., Fortino, K., Peterson, B. J., \& Ulseth, A. J. (2009). Stream food webs. In F. R. Hauer, \& G. A. Lamberti (Eds.), Methods in stream ecology (pp. 637-659). Amsterdam: Elsevier.

Hopkins, J. B., \& Ferguson, J. M. (2012). Correction: Estimating the diets of animals using stable isotopes and a comprehensive Bayesian mixing model. PLoS One, 7, e28478

Ibrahim, A. N. F., Noll Maria, S. M. C., \& Valenti, W. C. (2015). Zooplankton capturing by Nile Tilapia, Oreochromis niloticus (Teleostei: Cichlidae) throughout post-larval development. Zoologia, 32, 469-475.

Iverson, S. J. (2009). Tracing aquatic food webs using fatty acids: From qualitative indicators to quantitative determination. In M. T. Arts, M. T. Brett, \& M. Kainz (Eds.), Lipids in aquatic ecosystems (pp. 281-307). New York: Springer.

Jepsen, D. B., \& Winemiller, K. O. (2002). Structure of river food webs revealed by stable isotope ratios. Oikos, 96, 46-55.

Jones, G. E., \& Starkeyr, L. (1957). Fractionation of stable isotopes of sulfur by micro-organisms and their role in deposition of native sulfur. Applied Microbiology, 5, 111-118.

Kaplan, I. R., \& Rittenberg, S. C. (1964). Microbiological fractionation of sulfur isotopes. Journal of General Microbiology, 15, 96-101.

Khallaf, E. A., \& Alne-na-ei, A. A. (1987). Feeding ecology of Oreochromis niloticus (Linnaeus) \& Tilapia Zillii (Gervias) in a Nile canal. Hydrobiologia, 146, 57-62.

Kibret, T., \& Harrison, A. D. (1989). The benthic and weed bed faunas of Lake Hawassa (Rift Valley, Ethiopia). Hydrobiologia, 174, 1-15.

King, L., Maberly, S. C., De Ville, M. M., Kitschke, M., Gibson, C. E., \& Jones, R. I. (2009). Nitrogen stable isotope ratios of lake macrophytes in relation to growth form and nutrient-limitation. Fundamental and Applied Limnology, 175, 307-315.

Kupfer, A., Langel, R., Scheu, S., Himstedt, W., \& Maraun, M. (2006). Trophic ecology of a tropical Aquatic and terrestrial food web: Insights from stable isotopes (15N). Journal of Tropical Ecology, 22, 469-476.

Lakes Fisheries Development Program (LFDP) (1997). Lake Management Plans: Phase II, Working Paper 23. MOA.

Layman, C. A., Araujo, M. S., Boucek, R., Hammerschlag-Peyer, C. M., Harrison, E., et al. (2011). Applying stable isotopes to examine foodweb structure: An overview of analytical tools. Biological Reviews, 87, 545-562. https://doi.org/10.1111/j.1469-185X.2011.00208.x

Lazzaro, X. (1987). A review of planktivorous fishes: Their evolution, feeding, behaviours, selectivities and impacts. Hydrobiologia, 146, 97-167. https://doi.org/10.1007/BF00008764

Lazzaro, X. (1991). Feeding convergence in South American and African zooplanktivorous cichlids Geophagus brasiliensis andTilupiur endalli. Environmental Biology of Fishes, 31, 283-293.

Lorrain, A., Savoye, N., Chauvaud, L., Paulet, Y.-M., \& Naulet, N. (2003). Decarbonation and preservation method for the analysis of organic $C$ and $\mathrm{N}$ contents and stable isotope ratios of low-carbonated suspended particulate material. Analytica Chimica Acta, 491, 125-133.

Mao, Z. G., Gu, X. H., Zeng, Q. F., Gu, X. K., Li, X. G., \& Wang, Y. P. (2014). Production sources and food web of a macrophyte-dominated region in Lake Taihu, based on gut contents and stable isotope analyses. Journal of Great Lakes Research, 40, 656-665.

Mao, Z. G., Gu, X. H., Zeng, Q. F., Zhou, L. H., \& Sun, M. B. (2012). Food web structure of a shallow eutrophic lake (Lake Taihu, China) assessed by stable isotope analysis. Hydrobiologia, 683, 173-183.
Mavuti, K., Moreau, J., Munyadrorero, J., \& Plisnier, P. D. (1996). Analysis of trophic relationships in two shallow equatorial lakes Lake Naivasha (Kenya) and Lake lhema (Rwanda) using a multispecifies trophic model. Hydrobiologia, 321, 89-100.

McCutchan, J. H. Jr, Lewis, W. M., Kendall, C., \& McGrath, C. C. (2003). Variation in trophic shift for stable isotope ratios of carbon, nitrogen, and sulfur. Oikos, 102, 378-390.

McMeans, B. C., Olin, J. A., \& Benz, G. W. (2009). Stable-isotope comparisons between embryos and mothers of a placenta trophic shark species. Journal of Fish Biology, 75, 2464-2474.

Mengistou, S. (1989). Species Composition, Dynamics and Production of the Dominant crustacean Zooplankton in Lake Hawassa, Ethiopia. PhD Dissertation, University of Waterloo, Ontario, Canada.

Michener, R. H., \& Kaufman, L. S. (2007). Stable isotope ratios as tracers in marine food webs: An update. In R. Michener, \& K. Lajtha (Eds.), Stable isotopes in ecology and environmental science (pp. 238-278). Boston, MA: Blackwell Scientific.

Montoya, J. P. (2007). Natural abundance of $15 \mathrm{~N}$ in marine planktonic ecosystems. In R. Michener, \& K. Lajtha (Eds.), Stable isotopes in ecology and environmental science (pp. 176-201). Boston, MA: Blackwell Publishers.

Mook, W. G., Bommerson, J. C., \& Stavermen, W. H. (1974). Carbon isotope fractionation between dissolved bicarbonate and gaseous carbon dioxide. Earth Planetary Science Letters, 23, 169-179.

Moore, J. C., \& De Ruiter, P. C. (2012). Energetic foodwebs: An analysis of real and model ecosystems. Oxford University Press, United Kingdom.

Moriarty, D. J. W., \& Moriarty, C. M. (1973). The assimilation of carbon from phytoplankton by two Herbivorous fishes: Tilapia nilotica and Haplochromis nignipinnis. Zoological Society of London, 171, 41-55.

Parnell, A. C., Inger, R., Bearhop, S., \& Jackson, A. L. (2010). Source partitioning using stable isotopes: Coping with too much variation. PLoS ONE, 5(3), e9672. https://doi.org/10.1371/journal.pone.0009672

Parnell, A. C., Phillips, D. L., Bearhop, S., Semmens, B. X., Ward, E. J., Moore, J. W., et al. (2012). Bayesian stable isotope mixing models. Environmetrics, 24, 387-399.

Peterson, B. J., \& Fry, B. (1987). Stable isotopes in ecosystem studies. Annual Review of Ecology and Systematics, 18, 293-320.

Phillips, D. L., Inger, R., Bearhop, S., Jackson, A. L., Moore, J. W., Parnell, A. C., Semmens, B. X., \& Ward, E. J. (2014). Best practices for use of stable isotope mixing models in food-web studies. Canadian Journal of Zoology, 92, 823-835, https://doi.org/10.1139/cjz-2014-0127

Polis, G. A., \& Winemiller, K. O. (Eds.) (1996). FOOD WEBS: Integration pattern \& dynamic. Dordrecht, the Netherlands: Springer-Science+Business Media, B.V.

Post, D. M. (2002). Using stable isotopes to estimate trophic position: Models, methods, and assumptions. Ecology, 83, 703-718.

Rao, W., Ning, J., Zhong, P., Jeppesen, E., \& Liu, Z. (2015). Size-dependent feeding of omnivorous Nile tilapia in a macrophyte-dominated lake: Implications for lake management. Hydrobiologia, 749, 125-134. DOI https://doi.org/10.1007/s10750-014-2155-3

Raven, J. A., Johnston, A. M., Kubler, J. E., Korb, R., McInroy, S. G., Handley, L. L., Scrimgeour, C. M., Walker, D. I., Beardall, J., Vanderklift, M., Fredriksen, S., \& Dunton, K. H. (2002). Mechanistic interpretation of carbon isotope discrimination by marine macroalgae and sea grasses. Functional Plant Biology, 29, 355-378.

Reynolds, C. S. (1984). The ecology of freshwater phytoplankton. New York, USA. Cambridge University Press.

Ryan, C., McHugh, B., Trueman, C. N., Harrod, C., Berrow, S. D., \& O'Connor, I. (2012). Accounting for the effects of lipids in stable isotope (d13Candd15Nvalues) analysis of skin and blubber of balaenopterid whales. Rapid Communications in Mass Spectrometry, 26, 2745-2754. https://doi.org/10.1002/rcm.6394

Rybczynski, S. M., Walters, D. M., Fritz, K. M., \& Johnson, B. R. (2008). Comparing trophic position of stream fishes using stable isotope and gut contents analyses. Ecology of Freshwater Fish, 17, 199-206. 
Sanderson, S. L., Stebar, M. C., Ackermann, K. L., Jones, S. H., Batjakas, I. E., \& Kaufman, L. (1996). Mucus entrapment of particles by a suspensionfeeding tilapia (Pisces: Cichlidae). Journal of Experimental Biology, 199, 1743-1756.

Smyntek, P. M., Teece, M. A., Schulz, K. L., \& Thackeray, S. J. (2007). A standard protocol for stable isotope analysis of zooplankton in aquatic food web research using mass balance correction models. Limnology and Oceanography, 52, 2135-2146.

Tamire, G., \& Mengistou, S. (2014). Biomass and net aboveground primary productivity of macrophytes in relation to physico-chemical factors in the littoral zone of Lake Ziway, Ethiopia. Tropical Ecology, 55, 313-326.

Taylor, W. D., \& Gebre-Mariam, Z. (1989). Size-structure and productivity of the plankton community of an Ethiopian Rift Valley lake. Freshwater Biology, 21, 353-363.

Tilahun, G. (2007). Temporal Dynamics of the Species Composition Abundance and Size-fractionated Biomass and Primary Production of Phytoplankton in lakes Ziway, Hawassa and Chamo, Ethiopia. PhD Dissertation, Addis Ababa University, Ethiopia.
Wang, C., Lei, A., Zhou, K., Hu, Z., Hao, W., \& Yang, J. (2014). Growth and nitrogen uptake characteristics reveal outbreak mechanism of the opportunistic macroalga Gracilaria tenuistipitata. PLoS One, 9(10), e108980. https://doi.org/10.1371/journal.pone.0108980

Willén, E., Ahlgren, G., Tilahun, G., Spoof, L., Neffling, M.-R., \& Meriluoto, J. (2011). Cyanotoxin production in seven Ethiopian Rift Valley lakes. Inland Waters, 1, 81-91.

Yurkowski, D. J., Hussey, N. E., Semeniuk, C., Ferguson, S. H., \& Fisk, A. T. (2015). Effects of lipid extraction and the utility of lipid normalization models on $\mathrm{d} 13 \mathrm{C}$ and d $15 \mathrm{~N}$ values in Arctic marine mammal tissues. Polar Biology, 38, 131-143. https://doi.org/10.1007/s00300-014-1571-1 